Original Article. December 2018; 8(3): 51-67. Received: 28/02/2018 Accepted: 25/06/2018

http://dx.doi.org/10.21929/abavet2018.83.3

\title{
Productivity of Holstein dairy cows without shade at two seasons of the year
}

Productividad de vacas lecheras Holstein sin sombra en dos épocas del año Jesús Beauregard-García'asesorvaquero@live.com, Omar PradoRebolledo²omarpr@ucol.mx, Luis García-Márquez³ljgm_cmv@hotmail.com, Arturo García-Casillas ${ }^{4}$ cesargarciacasillas@hotmail.com, Rafael MacedoBarragán ${ }^{5}$ macedo@ucol.mx, Juan Hernández-Rivera ${ }^{2 *}$ jhernandez2@ucol.mx

${ }^{1}$ Inter-institutional Master in Animal Production. Mexico. ${ }^{2}$ Faculty of Veterinary Medicine and Zootechnics, University of Colima. Colima, Mexico. ${ }^{3}$ University Research Center for Agricultural Development, University of Colima. Colima, Mexico. ${ }^{4}$ Professor of the Inter-institutional Postgraduate in Animal Production. Mexico. ${ }^{5}$ Coordinator of the Inter-institutional Graduate in Animal Production. Mexico. *Responsible and correspondence author: Hernández Rivera Juan Augusto. Faculty of Veterinary Medicine and Zootechnics of the University of Colima; Kilometro 40 Carretera ColimaManzanillo, S / N, Tecomán, Colima, Mexico, CP 28100. E-mail: jhernandez2@ucol.mx

\section{ABSTRACT}

In order to evaluate the effect of season on the productivity of Holstein dairy cows in a commercial herd, 10 cows were assigned to one of two treatments, cows in winter (Inv) and cows in summer (Ver). The study lasted 70 days (d) divided into two periods of five weeks, respectively. The data were collected three times per week. The animals were under the same diet in both seasons, from an integral ration based on concentrate, alfalfa hay, and corn silage. The maximum temperature-humidity index was 70 and 75 units during the winter and summer, respectively. The cows in winter had lower $(\mathrm{P}<0.05)$ milk production, respiratory rate and rectal temperature than summer cows. The temperatures on the right flank and buttock area in winter cows were lower $(P<0.05)$, with respect to summer cows. Drinking water, floor, and environment temperatures through the black bulb were consistently lower $(P<0.05)$ during the winter season with respect to summer. Summer cows showed mild heat stress and increased $24 \%$ plus milk yield than winter cows, but did not improve milk quality. The use of shades during the summer can improve the physiological status milk quality in lactating dairy cows.

Keywords: Dairy cows, without shade, mild heat stress, productivity.

\section{RESUMEN}

Con el propósito de evaluar el efecto de época sobre la productividad de vacas lecheras Holstein, 10 vacas fueron asignadas a uno de dos tratamientos, vacas en invierno (Inv) y vacas en verano (Ver). El estudio tuvo una duración de 70 días (d) divididos en dos periodos de cinco semanas, respectivamente. Los datos fueron colectados tres veces por semana. Los animales fueron alimentados bajo el mismo régimen alimenticio en ambas épocas, a partir de una ración integral a base de concentrado, heno de alfalfa y silo de maíz. El índice de temperatura-humedad máximo fue de 70 y 75 unidades durante el invierno y verano, respectivamente. Las vacas Inv tuvieron menor producción de leche $(P<0.05)$, tasa respiratoria y temperatura rectal que vacas Ver. Las temperaturas de costado derecho y nalga en vacas Inv fueron menores $(P<0.05)$, respecto a vacas $\operatorname{Ver}(P<0.05)$. Las temperaturas de agua de bebida, piso y ambiental a través del bulbo negro fueron consistentemente menores $(P<0.05)$ durante la época de invierno con respecto al verano. Las vacas Ver presentaron estrés calórico ligero e incrementaron $24 \%$ más la producción de leche respecto a vacas Inv, pero no mejoraron la calidad en leche. El uso de sombras durante el verano, puede mejorar el estado fisiológico y calidad de la leche en vacas lecheras en lactación.

Palabras clave: Vacas lecheras, sin sombra, estrés calórico leve, productividad. 


\section{INTRODUCTION}

The increase in environment temperature (TA) has intensified mainly in desert and semidesert areas due to global warming, resulting in warmer summers (Avendaño et al., 2012). In addition to this, there are conditions such as heat stress (EC), which impact the livestockagriculture relationship in four important aspects: 1) grain production for livestock consumption, as well as availability and price, 2) production and quality of pasture and forage crops, 3) livestock production, reproduction, growth and health, and 4) disease distribution (Francis and Vavrus, 2012).

During 2011, high temperatures in the United States of America caused producers to suffer losses in milk production, which exceeded one trillion dollars (NOAA, 2012). The EC is described as an interaction between the increase in body temperature and internal heat, which is generated from the metabolism of nutrients coupled with the inefficiency of animals to lose body heat, in combination with environmental factors, such as: Relative humidity (HR), TA, wind speed and solar radiation (McManus et al., 2011). The latter is the main factor that ensures that animals gain heat directly or indirectly from the environment (Krishnan et al., 2017).

The temperature-humidity index (ITH) is used to quantify the degree of EC in animals and this starts from 72 units (West, 2003). On the other hand, from the physiological point of view and in order to minimize the heat coefficient, the cows first experience an increase in the rate of sweating, due to a redistribution of the blood towards the surface of the skin (Hernández et al. ., 2011; Habeeb et al., 2018). Also, these same authors mention that secondarily, organs such as the udder and the uterus decrease their functionality, altering the hormonal levels that have to do with the production and reproduction. In fact, animals that have been exposed to conditions of intense heat, showed an increase in the concentration of cortisol, which is directly related to the level of stress. They also showed a decrease in insulin, thyroxine, triiodothyronine (T3) and plasma aldosterone (Habeeb et al., 2018).

Conversely, it has been observed that animals under EC conditions, housed in shaded pens, have cortisol and plasma T3 in smaller and greater amounts respectively (Kamal et al., $2016^{b}$ ). Then the water consumption, rectal temperature (TR), pulse, respiratory rate (Three) and tachypnea are increased; finally, it decreases the consumption of nutrients and dry matter, rumination process and food passage rate (Kamal et al., 2016 , Kamal et al., 2016 ). Consequently, when the TA exceeds $29{ }^{\circ} \mathrm{C}$, the productive efficiency of dairy cows in lactation is usually reduced, mainly in cows that have been exposed to high temperatures for at least 67 days (Ammer et al., 2018).

The absence of shadows and high room temperatures are severe conditions, which can cause the death of dairy cows under EC (Rhoads et al., 2013). Therefore, the simple use of shadows in the pen helps to reduce the impact caused by CD in animals (Berman and 
Horovitz, 2012). In fact, it has been shown that animals that have been directly exposed to solar radiation can reduce the heat load in the shade from 30 to $45 \%$ (Ulvshammar, 2014).

Finally, in dairy herds located in northern Mexico, there have been reports of moderate to severe EC with ITH of 84 units during the summer months (Correa-Calderón et al., 2014, Anzures-Olvera et al., 2015). In certain regions of central Mexico, where traditionally it was not necessary to place shadows in the corrals, producers have begun to identify high temperatures, especially in the summer season; however, this has not been evaluated objectively, and it is likely that there is a negative effect on the productivity of dairy cattle.

Therefore, the objective of this study was to evaluate the effect of time on the quality and production of milk, physiological and climatic responses in lactating Holstein dairy cows, housed in shaded pens during the winter and summer in a commercial ranch of "El Marqués", Querétaro, Mexico.

\section{MATERIAL AND METHODS}

Location. The study was conducted in a commercial herd located at $20^{\circ} 44^{\prime} 00^{\prime \prime}$ North latitude, and $100^{\circ} 17^{\prime} 39^{\prime \prime}$ West longitude, in El Marqués municipality, Querétaro, Mexico; with an altitude of $1945 \mathrm{~m}$ a.s.l, average annual temperature of $18^{\circ} \mathrm{C}$ and annual rainfall of $500 \mathrm{~mm}$. The dominant wind is from Northeast to Southwest. The climate is predominantly semi-drytemperate in $87 \%$ of the municipality, the rest is temperate-sub-humid and sub-humid (INEGI, 2009).

Animals and treatments. The work was carried out during the winter and summer seasons, with a duration of 70 days divided into two periods of five weeks, respectively. The cows counted on a total area of $880 \mathrm{~m}^{2}$ inside the corral without shade, including $24.5 \mathrm{~m}$ of feeder in front. Taking into account, the days in milk (30 to $130 \mathrm{~d}$ ), number of births (2 to 5 ) and the production of milk prior to the beginning of the experiment and to give statistical normality to the data, 10 Holstein multiparous cows were assigned in a manner randomized to one of two treatments, (Inv); $(n=5)$ : cows in winter season; $(V e r) ;(n=5)$ : cows in summer time. The data were collected three times a week and the milking schedule was performed at 06:00 and 17:00 hours $(\mathrm{h})$, with duration of three and two hours, respectively; at the end of the milking, the food was already served in the trough to the floor. In both seasons, an integral ration was provided based on concentrate $(600 \mathrm{~g} / \mathrm{kg}$ of consumption), alfalfa hay ( $300 \mathrm{~g} / \mathrm{kg}$ of consumption), corn silage (100 $\mathrm{g} / \mathrm{kg}$ of consumption) and it was formulated according to the recommendations of the NRC (2001), containing $958 \mathrm{~g} / \mathrm{kg} \mathrm{MS}, 172 \mathrm{~g} / \mathrm{kg} \mathrm{PC}, 40.8 \mathrm{~g} / \mathrm{kg}$ of fat and $41.7 \mathrm{~g} / \mathrm{kg}$ of FDN. Access to water was ad libitum.

All the procedures performed on the animals were approved by the Bioethics Committee of the Faculty of Natural Sciences of the Autonomous University of Querétaro. 
Productive variables. Milk production was measured in kilograms per cow, during milking time; through the weighers of the WAIKATO brand (inter Ag, Hamilton, New Zealand). Immediately after the weigher, a milk sample was taken in plastic cups (50 ml) with cap; obtaining before closing the glass, the temperature of the milk $\left({ }^{\circ} \mathrm{C}\right)$, with the help of a digital thermometer in the form of a gun and an integrated infrared system (Fluke $®$ model 63 ). Finally, the milk was stored in a cooler for further analysis in the dairy laboratory of the Faculty of Engineering of the Autonomous University of Querétaro. To determine the quality of the milk, the components (protein, fat, non-fat solids, lactose and $\mathrm{pH}$ ) were obtained with the LACTOSCAN Milk Collecting Center (MCC, Bulgaria, 6000 Stara Zaragoza, 167, Tsar Simeon Veliki, A, 25).

From the total milk production (PLT) and the percentages obtained from fat and protein in milk, the energy variable in milk (EL) was obtained by the following formula, $E L=(\{[(40.72 \times$ fat, \% $+(22.65 \times$ protein, \% +102.77$] \div 1000\} \times 2,204) \times$ PTL (Tyrrell and Reid, 1965). In addition, with the information of PLT and percentage of fat in milk, milk production corrected to $3.5 \%$ fat was calculated (Parekh, 1986), using the formula: $L C G=[((0.425 \times P T L)+$ $(16425 \times(($ fat,$\% \div 100) \times \mathrm{PTL})))]$. Where: $\mathrm{LCG}=$ Milk corrected to $3.5 \%$ fat.

To estimate the projection at 305 days in milk (DEL) of the groups of cows Inv and Ver the formula proposed by Häubi Segura and Gutiérrez Lozano (2015), Proy305 = MilkDEL $\div$ CoefDEL $\times 100$, where: Proy305, is the estimate of the projection of milk per cow adjusted to $305 \mathrm{DEL}$; MilkDEL, is the production of milk on a specific day of the DEL; divided between CoefDEL, which is the coefficient corresponding to the same specific day of the LEDs, multiplied by 100. This coefficient was obtained from Wood's formula (1967) $=a \times t^{\wedge} b \times$ $\exp -c \times t$, where: $\mathrm{t}=$ days in milk $(\mathrm{DEL}) ; \mathrm{a}=0.434285 ; \mathrm{b}=0.318412 ; \mathrm{c}=0.142361\left(\mathrm{R}^{2}=\right.$ 0.995). Once the $305 \mathrm{DEL}$ projection of the Inv and Ver cow groups was obtained, the national average production (PMN) of milk for 2017 was requested from the Holstein Association of Mexico A.C. (AHM, 2018) and from these three data, the Winter, Summer and Control lactation curves were modeled, the latter created as a national reference for the Holstein breed.

The lactation curves were modeled by clearing the Proy305 formula, to obtain the kilos of milk corresponding to the LEDs of the $k g D E L=($ Proy305 $\div 100) \times$ CoefDEL curve. Finally, 0.1 was assigned to the first DEL, to reflect the milk production of the first hours after delivery, after the second DEL onwards; it is continued from 1 to 305 , corresponding to the days of a complete lactation.

Physiological variables. The body condition (CC) was evaluated once a week on a scale of five points, where "1" corresponded to a too skinny cow and " 5 " to a too obese one (Wildman et al., 1982). The temperature of the skin layer (TP) and Three were obtained at $1500 \mathrm{~h}$ inside the pens. The TR was obtained during the milking of the afternoon, for this a rod- 

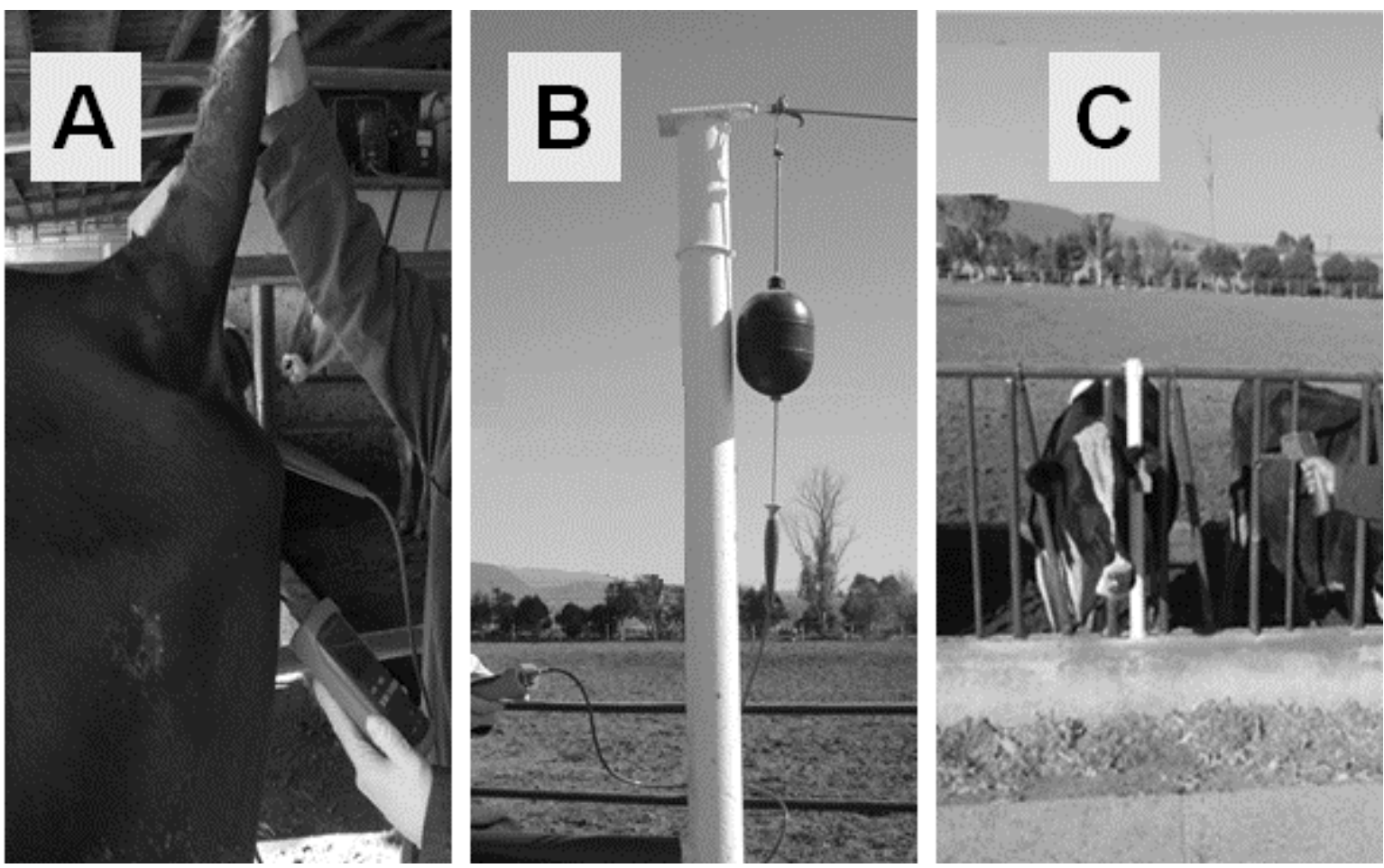

Figure 1. Rectal temperature readout $(\mathrm{A})$; reading of the room temperature through the black bulb, the rod-shaped attachment and digital thermometer (B); Take the temperature reading of the skin layer at a distance with the digital thermometer in the form of a gun and integrated laser (C).

shaped attachment was used and it was connected to a digital thermometer (Fluke $®$ models 80 PK-22 and 51-2, respectively, Figure 1-A).

The TA inside the pen was collected by using the black bulb, as suggested by Veissier et al. (2018), before each milking (Figure 1-B). For this, the same attachment and thermometer described in TR was used. On the other hand, with the digital thermometer in the form of a gun and integrated laser beam (Fluke ${ }^{\circledR}$ model 63 ), TP data were obtained in its different regions (Figure 1-C), such as: head, right side, buttock and udder of all animals in situ, therefore. It was necessary to do the evaluation at a distance of approximately three meters in relation to the cow, so as not to frighten them or provoke in them discomfort; the laser beam helped indicate the region and obtain accurate readings. Then, to obtain more information about the internal conditions of the corral, the temperatures of the drinking water and the ground floor were obtained, with the same thermometer described in TP, during the morning and afternoon, before starting the milking. Finally, the Three was determined from the number of breaths per minute (resp/min), observing the movement of the thorax of the cows.

Climatic variables. The meteorological status information was obtained daily from the experimental climatological station of the Faculty of Engineering of the Autonomous University of Querétaro, located $2 \mathrm{~km}$ from the study area. The climatic variables collected 
every fifteen minutes were TA $\left({ }^{\circ} \mathrm{C}\right)$ and $\mathrm{HR}(\%)$. Then the ITH was calculated with the following formula proposed by Hahn (1999): ITH = 0.81 TA + HR (TA-14.4) + 46.4. Where: $\mathrm{ITH}=$ Temperature-Humidity Index, $\mathrm{TA}=$ Ambient Temperature and HR = Humidity. Subsequently, averages, maximums and minimums of each variable were obtained.

Statistical analysis. All the variables were analyzed under a completely randomized design with $2 \times 5$ factorial arrangements, with the Proc Mixed procedure of the SAS (2004). The general statistical model used for each variable was $Y_{i j k}=\mu+E_{i}+S_{j}+\left(E_{i} \times S_{j}\right)+\varepsilon_{i j k}$ where: $Y$ ${ }_{i j k}$ is the dependent variable, $\mu$ is the general average, $E_{i}$ is the fixed effect of time, $S_{j}$ is the effect fixed week, $\left(E_{i} \times S_{j}\right)$ is the effect of interaction per week and $\varepsilon_{i j k}$ is the experimental error. The means and standard errors were recorded in each variable. To establish the differences between means, a least squares test was used and statistical significance was declared at a $5 \%$ probability, considering a tendency to a probability of $10 \%$.

\section{RESULTS AND DISCUSSION}

The records of the climatic variables during winter and summer are shown in figure 2. During the winter, the maximum value of TA was $20^{\circ} \mathrm{C}$ and $95 \% \mathrm{RH}$; while the ITH was 70 units; the minimum values were $3^{\circ} \mathrm{C}, 7 \%$ and 33 units, respectively. In the summer the maximum values of TA, HR and ITH were $30{ }^{\circ} \mathrm{C}, 95 \%$ and 75 units, respectively; and the minimum values $12{ }^{\circ} \mathrm{C}, 23 \%$ and 55 units, respectively.

These results coincide with that reported by Dalcin et al. (2016), where they obtained a maximum ITH of 75 units during the morning in Holstein dairy cows. The maximum HIT reached during the summer was maintained for at least $10 \mathrm{~h}$ each day; this means that the animals were subjected to a light EC. The rest of the day, the minimum ITH did not reach 60 units, which, as they did not present any type of EC, the animals had the opportunity to alleviate the heat obtained during the sunny hours (Silanikove and Koluman, 2015). Figure 3 shows the effect of epoch*week interaction $(P<0.01)$, with respect to the maximum and minimum values of ITH in the study time. During the summer, the minimum ITH remained constant at around 58 units in the five weeks of the study; while in the second week of winter the lowest point was recorded with 38 units. In the summer, the maximum ITH remained above 72 units for the first four weeks of study, reaching 75 units in the first week; however, less than 72 units were registered during the last week; on the other hand, in the winter the 70 units were not exceeded in any of the weeks.

ITH values less than 72 units, indicates that the animals are stress-free, that is, comfortable; from 72 to 78 units there is a slight stress; of $79-88$ units is moderate, and greater than 89 units is considered severe stress, in danger of death (Akyuz et al., 2010). Eigenberg et al. (2010) evaluated the effect of different types of shadows on dairy cows and discovered a lower EC load in them, when compared with animals housed in shaded pens, especially 


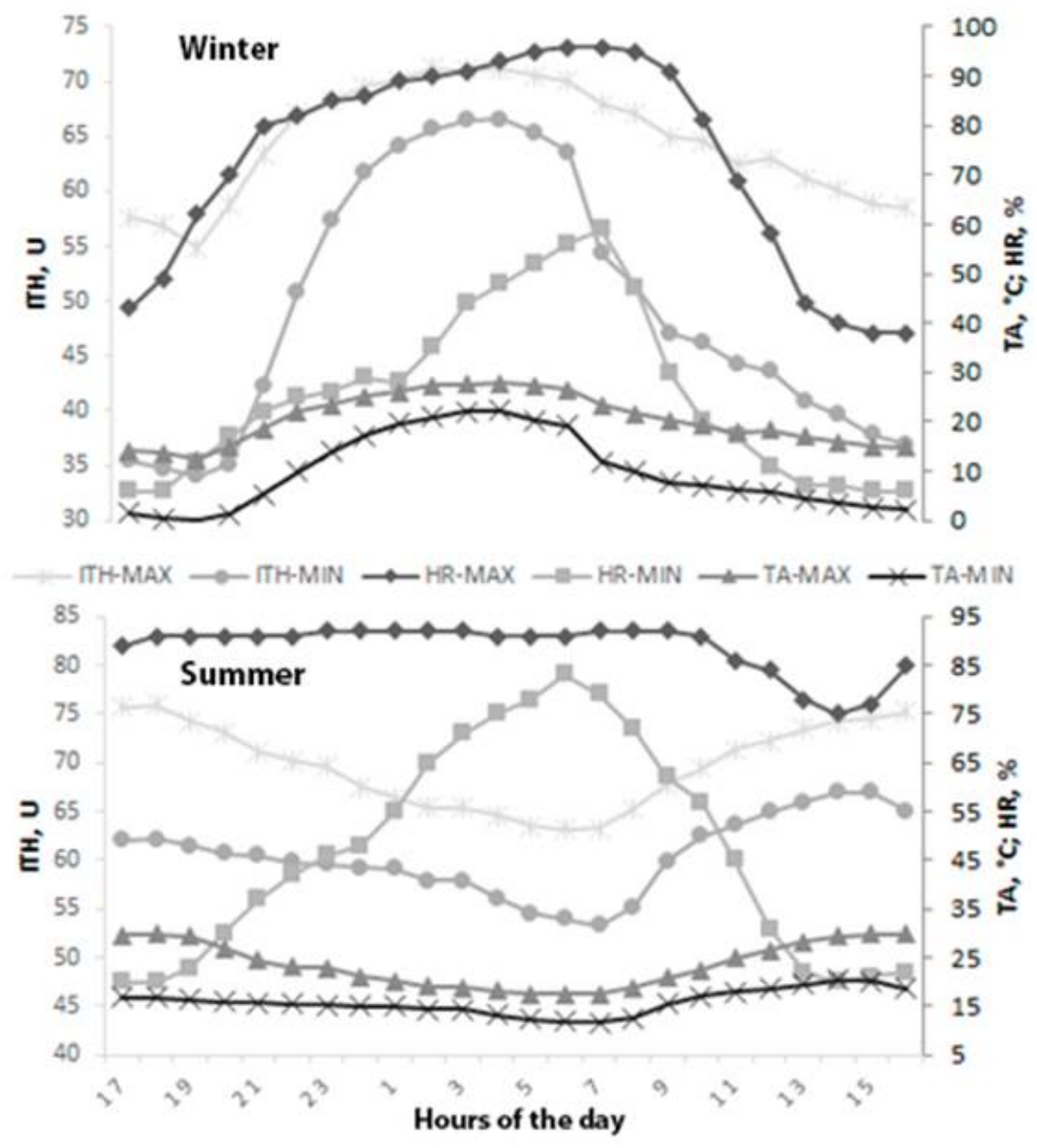

Figure 2. Hourly records of the temperature-humidity index (ITH), room temperature (TA) and relative humidity (HR) maximum and minimum during the winter and summer seasons

during daytime hours when high temperatures were recorded. Veissier et al. (2018) on the other hand, they estimated the percentage of time used by the cows under shade in the pen. These authors reported that the use of shade increased when the heat load in animals increased exponentially $(P<0.01)$.

The effect of epoch*weeks interaction had no effect $(P>0.05)$ on the productive, physiological responses and temperatures of drinking water, floor and black bulb. The results of the physiological variables are shown in Table 1 . The body condition of the cows was similar $(P>0.05)$ in both seasons; this indicates that the conditions of nutritional management were similar between the Inv and Ver animals. The Inv cows had lower $(P<0.05)$ Three and TR (45 rpm and $38.3^{\circ} \mathrm{C}$, respectively) than the Ver cows (56 rpm and $38.6{ }^{\circ} \mathrm{C}$ ), respectively).

According to this, it is evident that the Inv animals supported more the conditions of EC, with respect to the Ver cows. The Three, of Ver cows was above that reported by Dalcin et al. (2016) in Holstein x Gir animals housed without shade. The authors point out that these animals were more tolerant to EC, with respect to Holstein cows of the same study, which 

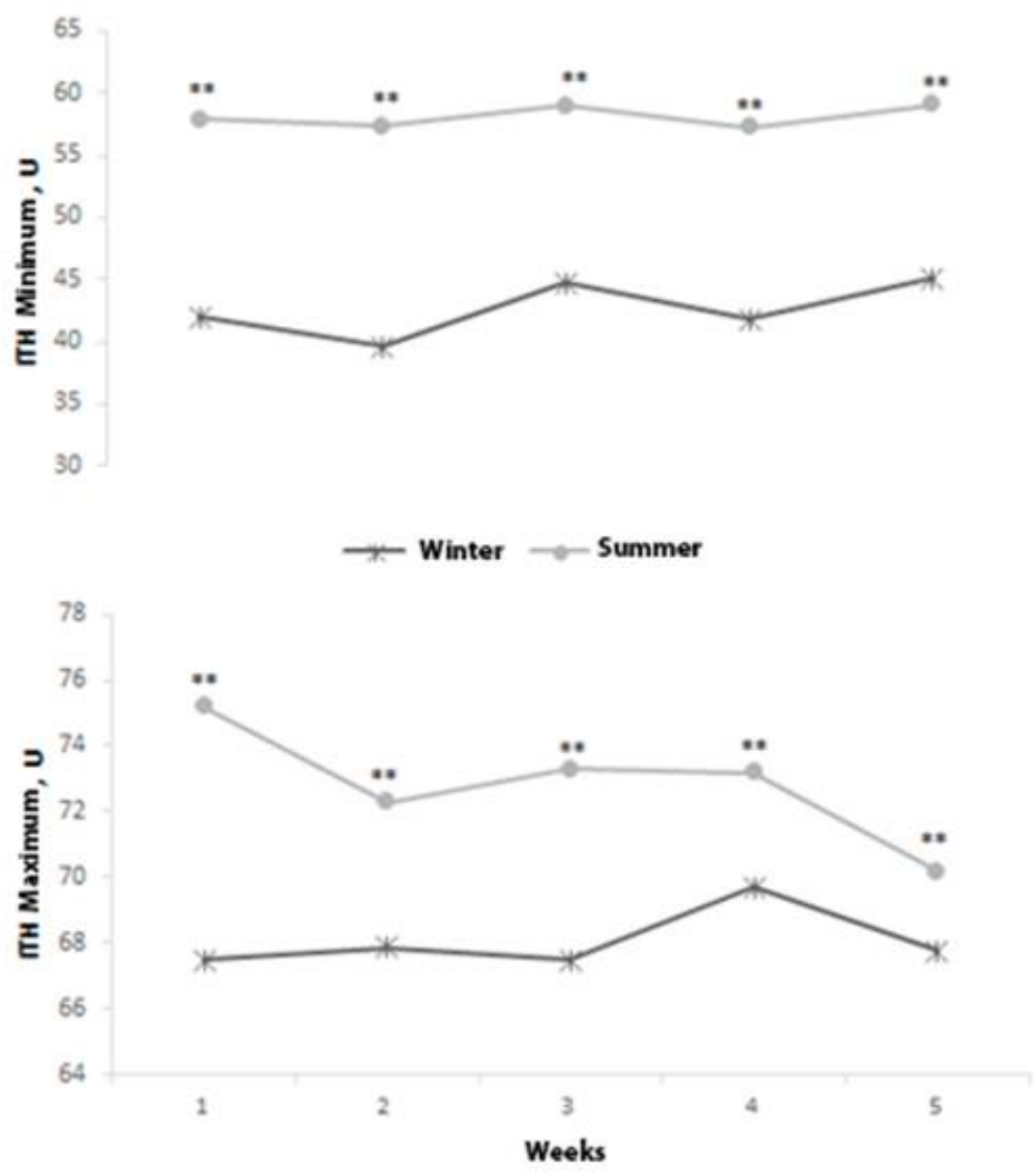

Figure 3. Weekly record of the maximum and minimum temperature-humidity index (ITH) of the group of winter and summer cows (differences between each point is shown with ${ }^{* *} P<0.01$ ).

Table 1. Effect of the winter-summer season on physiological responses in Holstein cows.

\begin{tabular}{ccccc}
\hline & Winter & Summer & E.E. & P-Value \\
\hline Body condition, 1-5 $^{2}$ & 3 & 3 & 0.0273 & 0.7710 \\
Respiratory rate $^{3}$ & 45 & 56 & 1.6186 & $<0.0001$ \\
Rectal temperature & 38.3 & 38.6 & 0.0434 & $<0.0001$ \\
Skin layer temperatures & & & & \\
Head & 34.8 & 35.6 & 0.8791 & 0.3517 \\
Right side & 34.2 & 36.1 & 0.7119 & 0.0105 \\
Buttock & 33.4 & 36.3 & 0.6584 & $<0.0001$ \\
Udder & 34.6 & 34.6 & 0.4088 & 0.9912 \\
\hline
\end{tabular}

${ }^{1}$ Standard error; ${ }^{2}$ units; ${ }^{3}$ breaths per minute; ${ }^{4}$ Celsius degrees.

presented $46 \mathrm{rpm}$ more than the cows of the Ver group. The normal Three in cattle is $20 \mathrm{rpm}$ (Thomas and Pearson, 1986) ; that is to say, that both groups of Inv and Ver cows increased by 125 and $180 \%$ plus the Three, respectively. 
Collier et al. (2017), mention that the increase of three and TR are important signs of EC in dairy cattle. Arias et al. (2018) indicate that when the TA exceeds $27^{\circ} \mathrm{C}$, the Three increases above $56 \mathrm{rpm}$. This situation was similar for the cows of the Ver group, with respect to those same variables. Fabris et al. (2017) reported that cows increase Three and TR from 77 units of ITH. This increase is in response to the fact that the hypothalamus detects EC conditions in animals through thermo receptors of the central and peripheral nervous system (Veissier et al., 2018). Likewise, Igono et al. (1992) indicated that the average TR in dairy cows is 38.5 ${ }^{\circ} \mathrm{C}$, under normal conditions. Tao and Dahl (2013) observed a positive correlation between the TR recorded in the afternoon and milk production. On the other hand, the TR was increased enough to detect a difference $(P<0.05)$ among the animals of the Ver group, with respect to the cows of the Inv group. This situation was similar to that reported by Veissier et al. (2018), when they observed that TR increased while EC increased in animals without shade. TPs such as the right and buttock sides of Inv cows $\left(34.2\right.$ and $33.4{ }^{\circ} \mathrm{C}$, respectively) were lower $(P<0.05)$ than cows in the Ver group $\left(36.1\right.$ and $36.3^{\circ} \mathrm{C}$, respectively).

Recently one study showed that animals under EC conditions but cooled in short periods of time, presented TP in leg and shoulder equivalent to those reported in the group of Inv cows (Tresoldi et al., 2018). On the other hand, in that same study, animals with shade and without cooling were similar to what was reported in cows of the Ver group. No differences $(P>0.05)$ were observed between the groups of Inv and Ver cows, with respect to the temperature of the head and udder.

The results of at least two TPs recorded in this study show a consistently higher increase in Ver cows than in Inv ones. This increase coincides with the results obtained in this study of Three and TR, during the same summer season. In addition, despite the fact that the Ver cows presented light EC, the animals did not compromise their eating and drinking activities inside the pen, as happened in a study carried out by Hernández et al. (2011). These same authors also reported that the increase in TP is associated with a higher rate of sweating and loss of body heat; in fact, in the need to stay cool, animals under EC conditions look for high places, preferably with shade, wind or constant air flow within the pen (Schütz et al., 2014; Van Laer et al., 2015; Kamal et al., 2018).

Table 2 shows the temperature results of the drinking water, floor and black bulb. The average temperatures of drink water, floor and black bulb were consistently higher $(P<0.05)$ in the group of Ver cows $\left(24.8,27\right.$ and $25.1^{\circ} \mathrm{C}$, respectively), than in the group of Inv cows $\left(18.8,20.0\right.$ and $21.9^{\circ} \mathrm{C}$, respectively); however, the temperature of the black bulb during the morning showed no difference $(P>0.05)$ in both groups of animals.

On the other hand, during the summer evenings the temperatures of drink water, floor and black bulb were considerably higher $(P<0.05)$ than in the winter evenings; which mean that these conditions improved the welfare of the group of Inv cows despite the absence of 
Table 2. Drinking water, floor and black bulb temperatures in the lodging pen during the winter-summer season

\begin{tabular}{ccccc}
\hline Temperatures $^{2}$ & Winter & Summer & E.E. $^{1}$ & P-Value \\
\hline Drinking water, $\mathrm{AM}^{3}$ & 15.0 & 23.0 & 0.4669 & $<0.0001$ \\
Drinking water, $\mathrm{PM}^{4}$ & 22.6 & 26.8 & 0.3430 & $<0.0001$ \\
Average & 18.8 & 24.8 & 0.2856 & $<0.0001$ \\
${\text { Floor, } \mathrm{AM}^{3}}$ & 15.5 & 18.8 & 0.5905 & $<0.0001$ \\
Floor, $\mathrm{PM}^{4}$ & 24.5 & 35.2 & 1.5372 & $<0.0001$ \\
Average & 20.0 & 27.0 & 0.8521 & $<0.0001$ \\
Black bulb, $\mathrm{AM}^{3}$ & 17.0 & 18.4 & 0.7578 & 0.0624 \\
Black bulb, $\mathrm{PM}^{4}$ & 26.8 & 31.8 & 0.6112 & $<0.0001$ \\
Average & 21.9 & 25.1 & 0.4634 & $<0.0001$ \\
\hline
\end{tabular}

${ }^{1}$ Standard error; ${ }^{2}$ degrees Celsius; ${ }^{3}$ morning reading; ${ }^{4}$ evening reading.

shadows. Then, as the dairy herd did not have facilities that would help mitigate the effects of solar radiation during the afternoon hours, it created a stressful environment that did not benefit the group of Ver cows; in fact, when the room temperature is higher than the TP, the animal gains heat from the surrounding environment, entering a state of discomfort (Avendaño-Reyes, 2012).

The results of the productive responses are shown in table 3 . The temperature in milk during the morning was lower $(P<0.05)$ in Inv cows than in the group of Ver cows, without presenting changes $(P>0.05)$ among the group of animals during the afternoon according to the results obtained in the climatic variables of this study.

The production of milk, LCG and energy in milk were higher $(P<0.05)$ in Ver cows, with respect to Inv cows. Milk production was greater by just over $5.5 \mathrm{~kg}$ between the two groups of animals; this is due to the fact that the Ver cows, when presenting a light EC, mainly during the hours of the day with higher intensity of heat, had the need to mitigate this stress through the increase in water consumption. Ammer et al. (2018) reported that Holstein dairy cows under EC conditions, increase water consumption by about $1 \mathrm{~L}$, per each unit of ITH increase.

In the case of Inv cows, as they did not present any kind of stress, they did not need to increase their water consumption; these assertions, although not recorded, are based on observations made during the development of the experiment. On the other hand, Polsky and von Keyserlingk (2017) mention that dairy cows in cases of dehydration due to EC, increase their activity, walking towards the feeders, drinking troughs and / or milking parlor; either individually or collectively. These same authors report that the routes of water loss in the body are through sweat on the skin, evaporation through panting, feces, urine and milk. Therefore, an increase in water consumption in animals under EC increases the amount of water in milk to release body heat; but it does not elevate the quality of it through its 
Table 3. Effect of time on productive responses of Holstein cows

\begin{tabular}{|c|c|c|c|c|}
\hline & Winter & Summer & E.E. ${ }^{1}$ & P-Value \\
\hline Milk $^{2}$ & 23.06 & 28.71 & 0.9053 & $<0.0001$ \\
\hline $\mathrm{LCG}^{3}$ al $3.5 \%$ & 24.50 & 30.62 & 1.2609 & $<0.0001$ \\
\hline Energy in milk ${ }^{4}$ & 16.22 & 20.14 & 0.7052 & $<0.0001$ \\
\hline Milk temperature $^{5}$, average & 31.41 & 32.50 & 0.2431 & $<0.0001$ \\
\hline $\mathrm{AM}^{6}$ & 31.19 & 33.11 & 0.4320 & $<0.0001$ \\
\hline $\mathrm{PM}^{7}$ & 31.64 & 31.95 & 0.2308 & 0.1840 \\
\hline $\mathrm{Fat}^{8}$, average & 3.71 & 3.72 & 0.09602 & 0.8734 \\
\hline $\mathrm{AM}^{6}$ & 3.20 & 2.89 & 0.09334 & 0.0014 \\
\hline $\mathrm{PM}^{7}$ & 4.20 & 4.56 & 0.1446 & 0.0127 \\
\hline Protein $^{8}$, average & 2.85 & 2.79 & 0.02609 & 0.0429 \\
\hline $\mathrm{AM}^{6}$ & 2.78 & 2.80 & 0.02972 & 0.6567 \\
\hline $\mathrm{PM}^{7}$ & 2.91 & 2.75 & 0.04785 & 0.0015 \\
\hline Lactose $^{8}$, average & 4.03 & 3.97 & 0.03564 & 0.0778 \\
\hline $\mathrm{AM}^{6}$ & 4.02 & 3.96 & 0.03520 & 0.0896 \\
\hline $\mathrm{PM}^{7}$ & 4.03 & 3.97 & 0.05665 & 0.3292 \\
\hline $\mathrm{SNG}^{9}$, average & 7.65 & 7.43 & 0.06629 & 0.0011 \\
\hline $\mathrm{AM}^{6}$ & 7.72 & 7.46 & 0.1050 & 0.0141 \\
\hline $\mathrm{PM}^{7}$ & 7.58 & 7.37 & 0.07053 & 0.0028 \\
\hline
\end{tabular}

${ }^{1}$ Standard error; ${ }^{2} \mathrm{~kg} / \mathrm{day} ;{ }^{3}$ milk corrected in fat at $3.5 \%$, kg; ${ }^{4} \mathrm{MCal} / \mathrm{d} ;{ }^{5}$ Celsius degrees;

${ }^{6}$ morning reading; ${ }^{7}$ evening reading; ${ }^{8}$ percent; ${ }^{9}$ non-fatty solids, percentage.

components. The non-fat solids were consistently higher $(P<0.05)$ in cows of the Inv group, when compared to cows See. Likewise, the percentage of fat during the morning was higher $(P<0.05)$ in cows Inv, compared to cows See; but during the afternoon the opposite happened, being higher $(P<0.05)$ in cows See that in cows Inv.

It has been reported that animals exposed to direct radiation from the sun, change the composition of fat in milk, with a concomitant reduction in levels of fatty acids and an increase in saturated fatty acids (SEVI et al., 2002). The percentage of lactose during the morning and afternoon were similar $(P>0.05)$ between the groups of Inv and Ver cows. The percentage of protein during the afternoon was higher $(P<0.05)$ in the group of Inv cows compared to the Ver cows. During the morning the percentage of protein was similar $(P>$ 0.05) between both groups of cows. Interestingly, the pattern of protein percentage in milk is usually affected by high temperatures. The epithelial cells of the mammary gland in EC conditions produce heat shock proteins, which reduce the protein synthesis in milk, directly causing a residual effect in lactation curves; and indirectly, it causes other effects on the pregnancy and the metabolic state of the cow (Collier et al., 2017).

The milk PMN for Holstein cows was $9853 \pm 1708 \mathrm{~kg}$ (AHM, 2018); the projection at 305 DEL for cows of the Inv and Ver group was $6037 \pm 1550$ and $7690 \pm 881 \mathrm{~kg}$, respectively. 


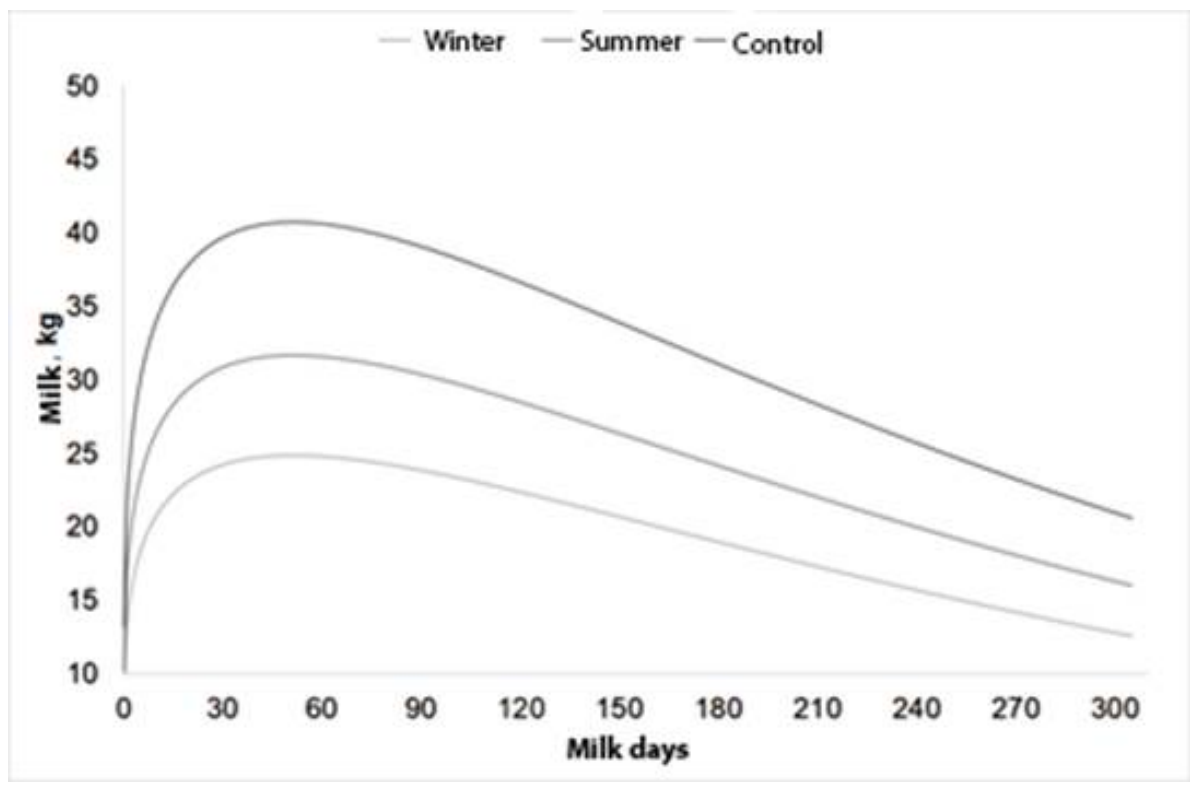

Figure 4. Production and projection curves at $\mathbf{3 0 5}$ days in milk of the group of cows Winter, Summer and Control.

Figure 4 shows the lactation curves at 305 DEL for the group of Inv, Ver and Control cows. The mathematical modeling of the curves indicated that the control group during the lactation peak exceeded the milk production by 15 and $10 \mathrm{~kg}$, with respect to Inv and Ver cows, respectively. In agreement with what was reported by Collier et al. (2017) these curves showed a clear decrease with respect to the control group, since both groups of Inv and Ver cows, did not manage to express from the genetic or environmental point of view the potential that the Witness group showed regarding the PMN of milk.

The components of milk quality in general showed, in most cases, to be lower $(P<0.05)$ in animals. Regarding Inv animals, which means that despite being greater the amount of fluid milk, it was lower the quantity of its components, which reinforces the argument of the presence of water in milk. Additionally, in some other cases, for example, the percentage of fat in milk showed similarities $(P>0.05)$ between the groups of Inv and Ver animals; which proportionally speaking turns out to be higher in the group of Inv cows than Ver ones. West (2003), reports that cows in the absence of shadows reduce the consumption of food and net blood flow to the digestive tract, resulting in a lower flow of nutrients to the mammary gland and lower milk quality.

\section{CONCLUSIONS}

The changes occurred in the physiological variables were more pronounced in the group of cows in summer, which presented light heat stress. During the study time, the cows of the group in winter did not show evidence of any type of heat stress. On the other hand, although the cows in summer produced $24 \%$ more milk than the cows in winter, they did not manage to improve the percentage of non-fatty solids. Finally, the use of shadows during the summer 
months can improve the physiological status and milk quality of lactating cows in "EI Marqués", Querétaro, Mexico.

\section{ACKNOWLEDGEMENT}

The authors are grateful for the support of the Autonomous University of Querétaro for the use of equipment and facilities for conducting this study. Likewise, they sincerely thank the IAZ. To Eduardo García Frías for his excellent availability in the use of cows in his dairy herd "La Haciendita".

\section{BIBLIOGRAPHY}

AHM. 2018. Control de producción. AHM Asociación Holstein de México A.C. Disponible: http://www.holstein.mx/srv_con.html.

AKYUZ A, Boyaci S, Çayli A. 2010. Determination of critical period for dairy cows using temperature humidity index. Journal of Animal and Veterinary Advances. 9:1824-1827. ISSN: 1680-5593. DOI: 10.3923/javaa.2010.1824.1827.

AMMER S, Lambertz C, Soosten D, Zimmer K, Meyer U, Dänicke S, Gauly M. 2018. Impact of diet composition and temperature-humidity index on water and dry matter intake of highyielding dairy cows. Journal of Animal Physiology and Animal Nutrition. 102(1):103-113. ISSN: 0931-2439. DOI: 10.1111/jpn.12664.

ANZURES-OLVERA F, Macías-Cruz U, Álvarez-Valenzuela F, Correa-Calderón A, DíazMolina R, Hernández-Rivera J, Avendaño-Reyes L. 2015. Efecto de época del año (verano vs. invierno) en variables fisiológicas, producción de leche y capacidad antioxidante de vacas Holstein en una zona árida del noroeste de México. Archivos de Medicina Veterinaria. 47:15-20. ISSN: 0301-732X. DOI: 10.4067/S0301-732X2015000100004.

ARIAS RA, Herrera C, Larraín R, González F, Mader TL, Velásquez A. 2018. Physiological and behavioural response of two dairy cows genotypes during summertime in the central region of Chile. Austral Journal Of Veterinary Sciences. 50:9-14. ISSN: 0719-8132. DOI: 10.4067/S0719-81322018000100103.

AVENDAÑO-REYES L. 2012. Heat stress management for milk production in arid zones. Milk Production-An Up-to-Date Overview of Animal Nutrition, Management and Health. DOI: $10.5772 / 51299$.

AVENDAÑO RL, Hernández RJA, Álvarez VFD, Macías CU, Díaz MR, Correa CA, Robinson PH, Fadel JG. 2012. Physiological and productive responses of multiparous lactating Holstein cows exposed to short-term cooling during severe summer conditions in an arid region of Mexico. International Journal of Biometeorology. 56(6):993-999. ISSN: 1432-1254. DOI: $10.1007 / \mathrm{s} 00484-011-0510-x$. 
BERMAN A, Horovitz T. 2012. Radiant heat loss, an unexploited path for heat stress reduction in shaded cattle. Journal of Dairy Science. 95(6):3021-3031. ISSN: 0022-0302. DOI: 10.3168/jds.2011-4844.

COLLIER RJ, Xiao Y, Bauman DE. 2017. Chapter 1 - Regulation of factors affecting milk yield. En: Nutrients in Dairy and their Implications on Health and Disease. Academic Press. 3-17 p. ISBN: 978-0-12-809762-5.

CORREA-CALDERÓN A, Gómez-Álvarez C, Avendaño-Reyes L, Diaz-Molina R, MedinaCervantes S, Rivera-Acuña F, Luna-Nevárez P, Macias-Cruz U. 2014. Efecto de la suplementación de progesterona y enfriamiento artificial post-inseminación sobre la eficiencia reproductiva de vaquillas Holstein durante el verano. Archivos de Medicina Veterinaria. 46:189-196. ISSN: 0301-732X. DOI: 10.4067/S0301-732X2014000200004.

DALCIN VC, Fischer V, Daltro DdS, Alfonzo EPM, Stumpf MT, Kolling GJ, Silva MVGBd, McManus C. 2016. Physiological parameters for thermal stress in dairy cattle. Revista Brasileira de Zootecnia. 45:458-465. ISSN: 1516-3598. DOI: 10.1590/ S1806-92902016000800006.

EIGENBERG RA, Brown-Brandl TM, Nienaber JA. 2010. Shade material evaluation using a cattle response model and meteorological instrumentation. International Journal of Biometeorology . 54(6):601-607. ISSN: 0020-7128. DOI: 10.1007/s00484-010-0381-6.

FABRIS TF, Laporta J, Corra FN, Torres YM, Kirk DJ, McLean DJ, Chapman JD, Dahl GE. 2017. Effect of nutritional immunomodulation and heat stress during the dry period on subsequent performance of cows. Journal of Dairy Science . 100(8):6733-6742. ISSN: 1525-3198 (Electronic) 0022-0302 (Linking). DOI: 10.3168/jds.2016-12313.

FRANCIS JA, Vavrus SJ. 2012. Evidence linking Arctic amplification to extreme weather in mid-latitudes. Geophysical Research Letters. 39(6). ISSN: 1944-8007. DOI: 10.1029/2012GL051000.

HABEEB A, Gad A, EL-Tarabany A, Atta M. 2018. Negative effects of heat stress on growth and milk production of farm animals. Journal of Animal Husbandry and Dairy Science. 2(1):1-12. Disponible: http://www.sryahwapublications.com/journal-of-animal-husbandry-anddairy-science/pdf/v2-i1/1.pdf

HAHN GL. 1999. Dynamic responses of cattle to thermal heat loads. Journal of Animal Science. 77(suppl_2):10-20. ISSN: 0021-8812. DOI: 10.2527/1997.77suppl_210x.

HÄUBI SEGURA CU, Gutiérrez Lozano JL. 2015. Evaluación de unidades familiares de producción lechera en Aguascalientes: estrategias para incrementar su producción y rentabilidad. Avances en Investigación Agropecuaria. 19(2):7-34. ISSN: 0188-7890. Disponible: http://www.redalyc.org/html/837/83742619002/. 
HERNÁNDEZ RJA, Álvarez VFD, Correa CA, Macías CU, Fadel JG, Robinson PH, Avendaño RL. 2011. Effect of short-term cooling on physiological and productive responses of primiparous Holstein cows exposed to elevated ambient temperatures. Acta Agriculturae Scandinavica, Section A - Animal Science. 61(1):34-39. ISSN: 0906-4702. DOI: 10.1080/09064702.2011.558910.

IGONO MO, Bjotvedt G, Sanford-Crane HT. 1992. Environmental profile and critical temperature effects on milk production of Holstein cows in desert climate. International Journal of Biometeorology . 36(2):77-87. ISSN: 1432-1254. DOI: 10.1007/bf01208917.

INEGI. 2009. Prontuario de información geográfica municipal de los Estados Unidos Mexicanos. Clave geoestadística 22011. Formato electrónico. Disponible: http:// www.beta.inegi.org.mx/app/biblioteca/ficha.html?upc=702825293116.

KAMAL R, Dutt T, Patel M, Dey A, Chandran PC, Bharti PK, Barari SK. 2016a. Behavioural, biochemical and hormonal responses of heat-stressed crossbred calves to different shade materials. Journal of Applied Animal Research. 44(1):347-354. ISSN: 0971-2119. DOI: 10.1080/09712119.2015.1074076.

KAMAL R, Dutt T, Patel B, Singh G, Chandran P, Dey A, Barari S. 2016b. Effect of shade materials on rectal temperature, respiration rate and body surface temperature of crossbred calves during rainy season. The Indian Journal of Animal Sciences. 86(1). ISSN: 0367-8318.

KAMAL R, Dutt T, Patel M, Dey A, Bharti PK, Chandran PC. 2018. Heat stress and effect of shade materials on hormonal and behavior response of dairy cattle: a review. Tropical Animal Health and Production.1-6. ISSN: 0049-4747. DOI: 10.1007/s11250-018-1542-6.

KRISHNAN G, Bagath M, Pragna P, Vidya MK, Aleena J, Archana PR, Sejian V, Bhatta R. 2017. Mitigation of the heat stress impact in livestock reproduction. Theriogenology. DOI: 10.5772/intechopen.69091.

MCMANUS C, Castanheira M, Paiva SR, Louvandini H, Fioravanti MCS, Paludo GR, Bianchini E, Corrêa PS. 2011. Use of multivariate analyses for determining heat tolerance in Brazilian cattle. Tropical Animal Health and Production . 43(3):623-630. ISSN: 0049-4747. DOI: $10.1007 / \mathrm{s} 11250-010-9742-8$.

NOAA. 2012. Billion-dollar weather/climate disasters, distribution and change: 2000 to 2010, summary statistics. NOAA's National Climatic Data Center. Disponible: http:// www.ncdc.noaa.gov/billions/summary-stats.

NRC. 2001. Nutrient requirements of dairy cattle. En. Washington, DC: The National Academies Pressp. ISBN: 978-0-309-06997-7. 
PAREKH H. 1986. A new formula for FCM (3.5\%) fat [Fat-corrected milk]. Indian Journal of Animal Sciences (India). ISSN: 0367-8318.

POLSKY L, von Keyserlingk MAG. 2017. Invited review: Effects of heat stress on dairy cattle welfare. Journal of Dairy Science . 100(11):8645-8657. ISSN: 0022-0302. DOI: 10.3168/ jds.2017-12651.

RHOADS RP, Baumgard LH, Suagee JK, Sanders SR. 2013. Nutritional interventions to alleviate the negative consequences of heat stress. Advances in Nutrition. 4(3):267-276. ISSN: 2161-8313. DOI: 10.3945/an.112.003376.

SAS. 2004. SAS/STAT User's guide software released. 9.12, v. SAS Institute Inc. Cary, NC.

SCHÜTZ KE, Cox NR, Tucker CB. 2014. A field study of the behavioral and physiological effects of varying amounts of shade for lactating cows at pasture. Journal of Dairy Science . 97(6):3599-3605. ISSN: 0022-0302. DOI: 10.3168/jds.2013-7649.

SEVI A, Rotunno T, Di Caterina R, Muscio A. 2002. Fatty acid composition of ewe milk as affected by solar radiation and high ambient temperature. Journal of dairy Research. 69(2):181-194. ISSN: 1469-7629. DOI: 10.1017/S0022029902005447.

SILANIKOVE N, Koluman N. 2015. Impact of climate change on the dairy industry in temperate zones: Predications on the overall negative impact and on the positive role of dairy goats in adaptation to earth warming. Small Ruminant Research. 123(1):27-34. ISSN: 0921-4488. DOI: 10.1016/j.smallrumres.2014.11.005.

TAO S, Dahl GE. 2013. Heat stress effects during late gestation on dry cows and their calves. Journal of Dairy Science . 96(7):4079-4093. ISSN: 0022-0302. DOI: 10.3168/ jds.2012-6278.

THOMAS CK, Pearson RA. 1986. Effects of ambient temperature and head cooling on energy expenditure, food intake and heat tolerance of Brahman and Brahman $\times$ Friesian cattle working on treadmills. Animal Science. 43(1):83-90. ISSN: 1357-7298. DOI: 10.1017/ S0003356100018353.

TRESOLDI G, Schütz KE, Tucker CB. 2018. Cooling cows with sprinklers: Spray duration affects physiological responses to heat load. Journal of Dairy Science . 101(5):4412-4423. ISSN: 0022-0302. DOI: 10.3168/jds.2017-13806.

TYRRELL HF, Reid JT. 1965. Prediction of the energy value of cow's milk. Journal of Dairy Science . 48(9):1215-1223. ISSN: 0022-0302. DOI: 10.3168/jds.S0022-0302(65)88430-2.

ULVSHAMMAR K. 2014. Effects of shade on milk production in Swedish dairy cows on pasture. Disponible: https://stud.epsilon.slu.se/6604/7/ulvshammar_k_140416.pdf. 
VAN LAER E, Tuyttens FA, Ampe B, Sonck B, Moons CP, Vandaele L. 2015. Effect of summer conditions and shade on the production and metabolism of Holstein dairy cows on pasture in temperate climate. Animal. 9(9):1547-1558. ISSN: 1751-732X (Electronic) 1751-7311 (Linking). DOI: 10.1017/S1751731115000816.

VEISSIER I, Van laer E, Palme R, Moons CPH, Ampe B, Sonck B, Andanson S, Tuyttens FAM. 2018. Heat stress in cows at pasture and benefit of shade in a temperate climate region. International Journal of Biometeorology . 62(4):585-595. ISSN: 1432-1254. DOI: 10.1007/s00484-017-1468-0.

WEST JW. 2003. Effects of heat-stress on production in dairy cattle. Journal of Dairy Science . 86(6):2131-2144. ISSN: $0022-0302$ (Print) 0022-0302 (Linking). DOI: 10.3168/ jds.S0022-0302(03)73803-X.

WILDMAN EE, Jones GM, Wagner PE, Boman RL, Troutt HF Jr, Lesch TN. 1982. A dairy cow body condition scoring system and its relationship to selected production characteristics. Journal of Dairy Science . 65(3):495-501. ISSN: 0022-0302. DOI: 10.3168/ jds.S0022-0302(82)82223-6.

WOOD PDP. 1967. Algebraic Model of the Lactation Curve in Cattle. Nature. 216:164. ISSN: 1476-4687. DOI: 10.1038/216164a0. 